\title{
How Propaganda Works: An Introduction
}

\begin{abstract}
Dan Zeman
University of Vienna

BIBLID [0873-626X (2018) 51; pp.275-288]

Abstract

This is the editor's introduction to the book symposium on Jason Stanley's influential book How Propaganda Words (Oxford University Press, 2015). After a few brief remarks situating the book in the landscape of current analytic philosophy, I offer a detailed presentation of each chapter of the book, in order to familiarize the reader with its main tenets and with the author's argumentative strategy. I flag the issues that the contributors to the symposium discuss, and describe their main points. I end with expressing hope that the symposium will help continue the conversation around ideology and propaganda within analytic philosophy.
\end{abstract}

\section{Keywords}

Propaganda, analytic philosophy, ideology, democracy, silencing.

The United States of America is considered a liberal democracythat is, a society that values liberty and whose deliberative process presupposes reasonableness. Yet, many pronouncements by politicians or the media have been taken to be propagandistic: those instilling fear of immigrants in the population, those painting exclusively negative portrayals of certain racial or religious groups, those decrying the destruction of "the American dream" etc. Similar tropes have been used in many other countries considered to be liberal democracies. How propaganda is possible in a liberal democracy, what forms it takes, what are its dangers for the democratic process and how it can be counterbalanced are the central questions of Jason Stanley's book How Propaganda Works.

Analytic philosophy has been often accused of dealing with abstract matters that find little application to social issues. While 
maybe true at certain times in its history, and for certain areas more than for others, this perception is clearly false when it comes to the topics analytic philosophy addresses today. Arguably, such topics still constitute a niche (or, better, several niches) rather than belonging to the mainstream, but they are on solid footing. By bringing tools from philosophy of language and epistemology to bear on social issues like ideology and propaganda, Stanley's book contributes to propelling this tendency within analytic philosophy into the mainstream, in an effort both to expand the latter's range and show its fruitfulness.

Since its appearance in 2015, How Propaganda Works has received quite a lot of attention, both within and outside analytic circles. Numerous reviews have been written, public intellectuals have expressed their opinions and several book symposia have been published by leading journals both in philosophy and political theory (Philosophy and Phenomenological Research, Theoria, Global Discourse). The present symposium follows suit, featuring three papers that engage with various issues from the book, together with Stanley's replies. In this short introduction, I offer a chapter-by-chapter description of Stanley's book as a reminder for the reader of its main tenets. I flag the issues that are discussed by the contributors, and briefly describe their main points. I leave the reader the pleasure of discovering Stanley's replies to the contributors' objections.

In "The Problem of Propaganda", the introduction of the book, Stanley situates his endeavor in the realm of "political rhetoric" a topic that has preoccupied philosophers since Plato and Aristotle, and clarifies that it is not a manual of propaganda, but an attempt to understand it and the mechanisms that make it effective. Thus, he starts off with Victor Klemperer's description in his book Language of the Third Reich (Klemperer 2006) of the effects of Nazi propaganda and its reliance on emotions-laden terms such as "heroism". According to Klemperer, the images and emotions that such terms conjure simply make rational deliberation impossible. Since rational deliberation is crucial in a democracy, the danger posed by propaganda for democracy is easy to see. Importantly, the claim that propaganda is dangerous for democracy holds across various ways of conceiving the latter. The essential connection that Stanley brings out in the introduction is that between propaganda and (flawed) ideology, and he lays down the challenges a theory of each faces: those facing the 
former are explaining its nature and effectiveness, while that facing the latter is to explain "voluntary servitude", in the words of Étienne de La Boétie (La Boétie 2012) — the tendency of negatively privileged groups to accept the flawed ideology of the elites. Finally, he asks the question of whether currently there are democracies where propaganda is present. Stanley's answer is an emphatic “yes", and he takes his main illustration to be the United States of America. The chapter ends with various examples in which a democratic language is used in the United States of America to mask an undemocratic reality.

Chapter 1, named "Propaganda in the History of Political Thought", is an incursion into the history of propaganda, with focus on the argument(s) that propaganda can be perilous for democracy. Thus, Stanley reviews arguments by Plato, Aristotle, Rousseau, Charles Mills and others to the effect that exercising the most central expression of the main democratic value-liberty (in the form of freedom of speech) — makes liberal democracy unstable. He also notes that recently this worry has not been present in political theorizing and connects this neglect with the way in which the relationship between normative and applied political philosophy is conceived. The main difference between the two is that, while the former studies democratic regimes as ideals or idealizations, the latter is left to deal with the "impurity" of actual democratic systems. But, closely following Mills 1997, 2005, Stanley claims that this way of understanding their relation misses the historical centrality of the problem and ends up ignoring "actual historic oppression and its legacy in the present, or current ongoing oppression" (Mills 2005: 168). Finally, drawing on several classical distinctions, and relying on a negative conception of liberty, Stanley concludes that the way to approach the problem is by taking silencing speech (in the sense theorized by Jennifer Hornsby and Rae Langton in Hornsby and Langton 1998 ) as the main way of restricting free speech rights. Since silencing speech is propagandistic, understanding it (and thus, the threat it poses to liberal democracy) requires an analysis of propaganda.

Chapter 2, "Propaganda Defined", is where Stanley starts this analytic enterprise, by arguing against two entrenched ways of construing propaganda to arrive at the definition he favors. Against the thesis that propaganda necessarily involves false claims ("the falsity condition”), Stanley provides both counterexamples (the sentence 
“There are Muslims among us" (2015: 42) is strictly speaking true, even when used in a propagandistic manner to instill fear of Muslims) and arguments meant to deflate the rejoinder that the false claims are not expressed, but communicated (misleading, for example, need not communicate false claims, yet it could count as propaganda). Stanley's main objection against the claim that propaganda consists of insincere claims ("the insincerity condition") is that it obscures the deep connections between propaganda and flawed ideological belief, the latter being investigated in full detail in chapters 5 and 6 .

After telling us what he doesn't take propaganda to be, Stanley puts forward his own positive conception. Its main ingredients are that propaganda aims to cut off rational debate by appealing to people's affective states and that it exploits an ideal. With these elements at hand, Stanley differentiates between supporting and undermining propaganda, the former defined as "[a] contribution to public discourse that is presented as an embodiment of certain ideals, yet is of a kind that tends to increase the realization of those very ideas by either emotional or other nonrational means" (2015: 53), the latter as a contribution that tends to "erode those very ideals" (2015: 53). Plenty of examples are given in the chapter, of both types. Further narrowing down the analysis, Stanley focuses on undermining propaganda in relation to political ideals - that is, undermining demagoguery, defined in concordance with the above as "[a] contribution to public discourse that is presented as an embodiment of a worthy political, economic or rational ideal, but is in the service of a goal that tends to undermine that very ideal" (2015: 69). Finally, Stanley considers several objections to this account of propaganda: that it is not politically useful, that it presupposes a neutral stance or that it is circular. In relation to the first (paralleling a similar objection raised for Sally Haslanger's account of oppression, developed in Haslanger 2012a), for example, talking about "worthy" political ideals introduces a certain degree of relativity, which leads to the complaint that the account falls short of giving clear verdicts on what counts as propaganda and what doesn't. Stanley's answer (following Haslanger's) is that the project here is to provide a metaphysics of propaganda, and not an epistemic criterion for recognizing it as such (thus leaving it open that some forms of propaganda will never be recognized as such). This is enough to allow one to expose certain arguments, 
insofar as they erode the ideals they are meant to serve, as propagandistic. The chapter ends with a few examples of non-demagogic propaganda - supporting propaganda in service of a worthy political ideal (e.g., stressing the physical beauty of one's country in order to motivate protecting its natural resources).

One of the issues tackled by Bianca Cepollaro and Giuliano Torrengo's paper, entitled "The Best and the Worst of Propaganda", is that of the definition of propaganda-namely, as essentially involving the use of emotion (see the first definition in the paragraph above). Contra that claim, the two authors make the point that there are cases that are rightfully catalogued as positive supporting propaganda, yet no appeal to emotion is present. As the main example to buttress their claim, they offer the (widespread) use of the feminine pronoun "she" in academic writing, which they take to amount to a form of affirmative action that thwarts the expectation that protagonists are always men and thus aimed at counterbalancing the unequal and unjust representation of women.

Chapter 3 ("Propaganda in Liberal Democracy") brings the focus on liberal democracies, Stanley's main interest in connection to the phenomenon considered. To apply the notion of propaganda to liberal democracies, we need to get clear on what their political ideals are (that is, we need to engage in normative political theory). Stanley notes that one type of such ideals are those governing public political discourse, a discourse that appears in political debate in elections, among representatives that seek to pass legislature in the chambers of government and in media discussions of both. Those ideals pertain to the ideals of public reason (analyzed by John Rawls in Rawls 2005, for example), which are the standards that ought to guide public political discourse, and which imply (at the minimum) fair deliberation and equal representation of all citizens. The main question here is what makes a deliberative joint process fair. Thus, Stanley investigates three normative ideals of public political discourse: theoretical rationality, practical rationality, and reasonableness. Ultimately, Stanley settles for the latter, which is conceived by Rawls as requiring from any contribution to political discussion to be justifiable to all those it concerns. Reasonableness involves, according to W. E. B. Du Bois (1994), Susan Stebbing (1939), Manfred Stanley (1983) and Stephen Darwall (2006), all of whom Stanley follows here, cognitive 
empathy - the capacity to put oneself in others' shoes and of treating them with dignity and respect. Paradigmatic cases of propaganda, then, are "ones that are presented as reasonable, but that subsequently make it more difficult for the participants in the debate to be reasonable" (2015: 108); in other words, they erode reasonableness.

In the second part of the chapter, Stanley shows, taking as a starting point the traditional notion of "defending rhetoric", that propaganda can play a positive role - that is, that it can take the form of civic rhetoric, whose use is politically necessary "to overcome fundamental obstacles to the realization of democratic ideals" (2015: 109-10). His main example is the debate between W. E. B. Du Bois and Alain Locke in the 1920s about the usefulness of using propaganda by Black artists to transmit the message that Blacks deserve equal respect as humans and citizens. As for the method by which civic rhetoric operates, Stanley submits that it is by employing the liberal democratic ideals themselves (in the case of Du Bois 1926, freedom) against a certain (limited) understanding of them and in order to expand their range to those previously left outside their purview. Civil rhetoric thus sits in stark contrast to demagoguery: one increases reasonableness, the other erodes it. The parallel analysis of the two completes the picture of the main forms of propaganda found in (faulty) liberal democracies.

In "Language as a Mechanism of Control", the fourth chapter of the book, Stanley deploys known tools from analytic philosophy of language to paint a comprehensive picture of how propaganda works. To this aim, Stanley exploits a truth-conditional theory of meaning and takes the fact that it explains successful communication to make it suitable to provide a grasp of what happens when communication fails, as in propagandistic manipulation. The starting point of the analysis is the idea, proposed by various philosophers in the feminist tradition (e.g., Catharine MacKinnon, Jennifer Hornsby, Rae Langton) that certain types of speech have the function of subordinating certain groups. Focusing on linguistic propaganda (as opposed to imagistic and other of its forms), Stanley introduces a number of familiar concepts from current philosophy of language and shows how they come together to achieve his purpose: linguistic context (a notion central in contemporary semantics and pragmatics), common ground (a notion introduced by Robert Stalnaker and discussed in detail in, 
e.g., Stalnaker 2002), ranking (a development of the Stalnakerian notion of common ground by Frank Veltman (1996) and William Starr (forthcoming), and applied to subordinating speech by Ishani Maitra (2012)), social meaning (Dan Kahan's term from Kahan 1997). Importantly, two types of content are distinguished in this framework: at-issue content and not-at-issue content. The former is what one proposes to add to the common ground (what is taken to be commonly accepted by interlocutors), and can be easily rejected; the latter is what is not openly proposed, but rather smuggled into the common ground, and is much harder (or in some cases impossible without breaking the conversation) to reject.

Here, at this second level of content, is where propaganda thrives. Words have social meanings, which can amount to contents like stereotypes, but can also be commands or instructions to prefer certain situations over others (via the ranking mentioned above). By repeated association of a word with a certain social meaning, the latter becomes encoded in the word's conventional meaning, and thus gets communicated when the word is employed. Social meanings appear at the level of not-at-issue content, and they serve to stifle political deliberation by eroding empathy or by excluding the perspective of certain groups. Stanley discusses two ways in which propagandistic effects can be achieved: according to what he calls "the content model", the at-issue content is reasonable, but the not-at-issue content is unreasonable; according to what he calls "the expressive model", the at-issue content is reasonable, but the words used have not-at-issue emotional effects. Since both erode empathy and aim to exclude the perspective of certain groups, both models are fit for the analysis of propaganda (Stanley himself holds a disjunctive view). One of Stanley's examples to illustrate this mechanism is the term "welfare": it can be used to convey a content that makes a reasonable claim (say, a preoccupation with the wellbeing of citizens) but at the same time conveys its social meaning - the content that Blacks are lazy, for example, or an emotional effect that evinces the desire to avoid Blacks. Interestingly, Stanley connects the discussion of such "code words" with that of slurs and draws certain methodological consequences for the way philosophy of language has approached them. Noting that, precisely because of their openly derogatory character, slurs have become unacceptable in the public discourse of contemporary democratic societies, Stanley 
claims that the recent focus on slurs, as a special type of expressions, is misguided. While both slurs and code words encode social meanings that exclude certain groups from public deliberation (thus having the same function in discourse), it is the latter that are more important to study, since they are the ones mostly used in propagandistic manipulation. Stanley also briefly notes that there are other mechanisms for achieving propagandistic effects, different from the one described in detail in the chapter. Thus, restricting the domain of quantifiers like "everyone", the strategic use of personal pronouns like "we", even names (a telling example being Klemperer's discussion of German names under the Third Reich) can exclude certain individuals from a group, divide people in opposite groups (us and them), signal that one is a part of a group by bearing the "right" name etc. The last part of the chapter is dedicated to tackling various issues that arise once we acknowledge that communication is so often indirect and complexthe most important being that about the role and possibility of norms of public reason in a democracy. After mentioning and rejecting John Dewey's notion of "regulative ideal" (proposed in Dewey 1954), the related notion of "faith in the democratic process", and an analogy with ideals in science, Stanley eventually settles on adopting "systematic openness to the possibility that one has been unknowingly swayed by bias" (2015: 176) as a viable norm.

It is issues from this chapter that Olúfémi O. Táiwò's contribution, entitled "The Empire Has No Clothes", chiefly addresses. Táiwò's main aim in the paper is to propose what he calls a "practice first" view of propaganda, which he sees as opposed to the common notion (adopted by Stanley, too) that gives beliefs the primary role. Táíwò objects to Stanley's dichotomy between at-issue and not-atissue content and to his understanding of common ground. He thus proposes a supplementation of the latter in order to include nondoxastic elements, such as warrants and incentives, which are social in nature and are essentially connected with social behavior. This is what Táíwo calls "agenda setting", understood as effecting changes to the common ground's associated incentive structure. Agenda setting, however, extends well beyond conversational practices into non-conversational phenomena like "rent prices, unemployment rates, and terrorism" and thus provides a unified analysis of what only appear to be disparate phenomena while preserving the predictive capacity 
of belief-based views. Táíwò also draws out the possible advantages the practice first view has in connection to other issues in social and political philosophy, brought to the fore, for example, by Miranda Fricker's concept of "epistemic injustice" (Fricker 2007) or Charles Mills" analysis of "white ignorance" (Mills 2007).

The second point of Cepollaro and Torrengo's contribution also tackles an issue that appears in this chapter-namely, Stanley's claim that slurs are not special in comparison to other types of natural language expressions (in particular, code words). The two authors argue for the special character of slurs by contrasting them with code words: since there are cases in which the latter are used without their social meaning being communicated, but no cases in which the former are used without their social meaning being communicated, there is a crucial difference between the two types of expressions. This vindicates, in the authors' view, the special treatment slurs have received in current literature.

Chapter 5 ("Ideology") tackles the epistemological aspects of propaganda, and Stanley's aim in it is to spell out a politically significant way in which beliefs are resistant to evidence-a problem that has been at the center of the philosophy of, for example, David Hume. In A Treatise of Human Nature, Hume asked why is it that certain beliefs (e.g., the belief that there are external things) are so hard to revise in light of evidence and found the culprit in our flawed psychology. In contrast to Hume, Stanley is interested primarily not in flawed psychologies, but in flawed social structures that give raise to ideological beliefs. Thus, he sees ideological beliefs as connected to social identities, having the role of legitimating them. Social identities are "constituted by the practices and habits in which we engage; those we engage with are our community" (2015: 185). Thus, following Haslanger 2012b, Stanley sees ideologies as social scripts that govern one's normative and practical expectations. This aspect explains why ideological beliefs are so hard to abandon or rationally revise: they are "cherished beliefs" (a notion introduced by Stebbing 1939) and contain "stereotypes' (in Walter Lippmann's sense, described at length in Lippmann 2010). This way of understanding ideological beliefs allows Stanley to oppose drawing an ontological distinction between beliefs that are rationally revisable and those that are not (as that proposed by Tamar Gendler with the introduction of a new 
mental category designated by the term "alief" in Gendler 2008). The final claim in this chain of reasoning is that flawed ideological beliefs are not only morally and politically wrong, but in addition have a characteristic epistemological defect which is more fundamental, in that their moral and political flaws are a consequence of the epistemological one: namely, they "prevent us from gaining knowledge about features of reality, including social reality" (2015: 198). Since some of these features are the domain of democratic policy, flawed ideological beliefs crucially affect democratic decision making. Stanley shows further that not only beliefs can impede us from gaining social knowledge, but also conceptual schemes (relying on an example discussed by Iris Murdoch in Murdoch 1970) and concepts (using Sojourner Truth's analysis of the concept "woman", discussed in Collins 2000, and cases of "hermeneutical injustice" put forward by Fricker 2007). Importantly, Stanley reviews a wide range of recent empirical evidence to the effect that our beliefs - including our perceptual beliefs, which we might think are the golden gateway to a mind-independent reality — are tainted by background biases (Susanna Siegel's term "perceptual farce" from Siegel 2014 is most apt here), including those regarding structural facts about society. The final part of the chapter is dedicated to responding to the objection that an account of ideology and propaganda is itself ideological. While admitting that this might influence the choice of examples and their political significance, Stanley finds no reason to question the objectivity of his account, as it builds on ordinary elements found in the philosophy of language, epistemology and social psychology.

Chapter 6, entitled "Political Ideologies", connects issues from the previous chapter to the thread left open in chapter 3 , where the focus of investigation was propaganda in liberal democracies. Specifically, Stanley is here interested in certain flawed ideologies that arise in societies with an unjust distribution of resources and in explaining how they are pernicious for democracy. Even more specifically, the flawed ideology under examination is that the positively privileged "will believe they deserve the privileges they obtain as a result of accidental forces" (2015: 225) — a claim forcefully made, for example, by the sociologist Max Weber (1967). Members of such groups develop "legitimizing myths", evidence for which comes from the self-affirmation theory (proposed by the psychologist Claude Steele in Steele 1988) 
and from various studies about the political leanings of the wealthy or of lottery winners. Another source of such a flawed ideology is ideological uniformity, as the literature on "motivated reasoning" shows.

A crucial issue that the chapter tackles is why flawed ideologies of the kind mentioned are embraced not only by the positively privileged, but by those negatively privileged as well (also a claim made by Weber 1967). Stanley argues at length for the claim that this is indeed so, mainly by responding to two possible objections: namely, that by buying into the ideology of the elites, the negatively privileged act against their own interests and that the negatively privileged have plenty of evidence of the social realities that contradict the ideology. Stanley's strategy in responding to these worries is, again, a closer look at the process of belief formation. Thus, he points out the role of the school system and of the media as "ideological state apparatuses", brings in more empirical evidence (this time about the phenomenon of "stereotype threat") and describes the mechanism of trusting "experts" on moral issues (insights into which have been provided by the famous experiments done by Stanley Milgram - see, e.g., Milgram 1965). Another source of support for the claim comes from analytic epistemology. In previous work, Stanley has defended what is known as the "interest-relativity of knowledge" - the thesis that those in high-stakes situations need a higher threshold of evidence for their beliefs to count as knowledge than those in low-stakes situations. Stanley claims that this thesis can help show why the negatively privileged are epistemically oppressed (in the sense of the phrase theorized by Kristie Dotson in Dotson 2012). Under the reasonable assumption that those negatively privileged are in high-stakes situations, it follows that they have harder access to knowledge, and, given the connection between knowledge and action, that they are prevented from rationally choosing their actions. Moreover, given the connection between knowledge and assertion, they are also at a loss in democratic deliberation. However, Stanley argues that one need not accept his thesis to hold that the negatively privileged are epistemically oppressed: the same conclusion holds under three alternative explanations of the data (the thesis that it is belief, not knowledge, for which the threshold is higher in high-stakes situations, the thesis that confidence is shaken by stress in high-stakes situations and the thesis that high-stakes situations increase reasonableness, but those in them 
are perceived as subject to "wishful thinking"). Finally, Stanley also holds that flawed ideologies formed in conditions of inequality harm not only the negatively privileged, but also the positively privileged, by denying them access to knowledge of social facts, by robbing them of autonomous action and by making them act against their own ethical interests. "Inequality", Stanley concludes, "is epistemologically problematic for everyone" (2015: 266).

Maria Cristina Amoretti's contribution to the symposium, "Flawed Ideologies, Propaganda and the Social Situatedness of Knowledge", addresses issues from the two chapters just summarized. More precisely, she focuses on the relation between Stanley's take on flawed ideologies and propaganda, on the one hand, and the thesis of the social situatedness of knowledge (a thesis developed mostly within feminist epistemology), on the other. Thus, Amoretti explores how well some of Stanley's claims fit with the tenets of standpoint theory and with those of social empiricism, respectively, and claims that, while they undermine the former, they support the latter. By relying on Stanley's claims about the epistemological situation of individuals from both positively and negatively privileged groups caught in the grip of flawed ideologies, Amoretti concludes that the project in How Propaganda Works can help develop the broad idea of the social situatedness of knowledge along social empiricist lines.

Finally, chapter 7 ("The Ideology of the Elites: A Case Study") is - as its name suggests - a case study meant to illustrate the main idea of the book, namely that elites adopt flawed ideologies in order to justify the excessive control they have over the goods of the society in which they are born. Thus, Stanley focuses on a particular historical example: the reorganization of the secondary school system at the beginning of the twentieth century in the United States of America. He connects the specific proposals to an entrenched distinction in European culture: that between manual and intellectual labor, mere practical skill and theoretical knowledge. He also considers contemporary defenses of this idea in neuroscience which, by relying on his own previous work, he rejects. Stanley then shows how, by focusing on the ideal of social efficiency instead of that of liberty, the pedagogues at the beginning of the twentieth century have managed to distort the meaning of democracy and impose a school system that favors theoretical knowledge over skill, thus heralding elites as those guiding society as a 
whole. By showing how the educational system can be used to enforce social control, Stanley supports his conclusion that experts, although essential in a society, cannot be left to dictate matters of value.

In the short conclusion of the book, Stanley describes it as being "in the service of warning of false hope of realized ideals" (2015: 292). The warning is that, by assimilating the results of progressive social movements in a rhetoric of progress, the gap between ideal and reality is obscured. Philosophy can also contribute to this by not addressing the respective gaps. In liberal democracies, the role of masking actual inequalities is played precisely by propaganda, which shows why its study is crucial for the good functioning of a democracy.

Although this symposium comes late to the table, the contributions within it both tackle issues that continue those already present in the vast discussion that How Propaganda Works has sparked and open up new avenues for debate - thus confirming the book's usefulness for the study of propaganda and for the field of analytic philosophy in general. As someone interested in such issues, I am grateful for the opportunity of helping continue the conversation. I wholeheartedly thank the participants, the reviewers, the editors ${ }^{1}$ of Disputatio and, of course, Jason Stanley, who has not given up on this project during the troubled times we are currently living in.

Dan Zeman

University of Vienna

\section{References}

Collins, P. H. 2000. Black Feminist Thought: Knowledge, Consciousness, and the Politics of Empowerment. New York: Routledge.

Darwall, S. 2006. The Second Person Standpoint: Morality, Respect, and Accountability. Cambridge, Mass.: Harvard University Press.

Dewey, C. 1927. The Public and Its Problems. Athens: Swallow Press, 1954.

Dotson, K. 2012. A cautionary tale: on limiting epistemic oppression. Frontiers. A Journal of Women Studies 33(1): 24-47.

Du Bois, W.E.B. 1926. Criteria of Negro art. The Crisis 32: 290-7.

Du Bois, W.E.B. 1903. The Souls of Black Folk. New York: Dover, 1994.

Fricker, M. 2007. Epistemic Injustice: Power and the Ethics of Knowing. Oxford:

${ }^{1}$ With special thanks to José Manuel Mestre, whose comments have improved this Introduction. 
Oxford University Press.

Gendler, T. 2008. Alief and belief. The Journal of Philosophy 105(10): 634-63.

Haslanger, S. 2012a. Oppressions. In S. Haslanger, Resisting Reality: Social Construction and Social Critique, pp. 311-37. Oxford: Oxford University Press.

Haslanger, S. 2012b. Ideology, generics, and common ground. In S. Haslanger, Resisting Reality: Social Construction and Social Critique, pp. 446-75. Oxford: Oxford University Press.

Hornsby, J. and Langton, R. 1998. Free speech and illocution. Legal Theory 4(1): 21-37.

Kahan, D. 1997. Social influence, social meaning, and deterrence. Virginia Law Review 83(2): 349-95.

Klemperer, V. 1947. Language of the Third Reich: LTI, Linguii Tertii Imperii. Translated by Martin Brady. London: Continuum, 2006.

La Boétie, Etienne de. 2012 Discourse on Voluntary Servitude. Translated by James Atkinson and David Sices. Indianapolis: Hackett Publishing.

Lippmann, W. 1922. Public Opinion. Sioux Falls: Greenbook, 2010.

Maitra, I. 2012. Subordinating speech. In Speech and Harm: Controversies over Free Speech, ed. by I. Maitra and K. McGowan, pp. 94-120. Oxford: Oxford University Press.

Milgram, S. 1965. Some conditions of obedience and disobedience to authority. In S. Milgram, The Individual in a Social World, pp. 102-23. Reading, Mass.: Addison-Wesley.

Mills, C. 1997. The Racial Contract. Ithaca: Cornell University Press.

Mills, C. 2005. "Ideal theory" as ideology. Hypatia 20(3): 165-83.

Mills, C. 2007. White ignorance. In Race and Epistemologies of Ignorance, ed. by S. Sullivan and N. Tuana, pp. 11-38. Albany: State University of New York Press.

Murdoch, I. 1970. The idea of perfection. In I. Murdoch, The Sovereignty of Good, pp. 1-44. New York: Routledge and Kegan Paul.

Rawls, J. 1993. Political Liberalism (Expanded Edition). New York: Columbia University Press, 2005.

Stanley, J. 2015. How Propaganda Works. Princeton: Princeton University Press.

Stanley, M. 1983. The mystery of the commons: on the indispensability of civic rhetoric. Social Research 50(4): 851-83.

Siegel, S. 2014. Afterword: epistemic evaluability and perceptual farce. In Cognitive Effects on Perception: New Philosophical Perspectives, ed. by J. Zeimbekis and A. Raftopoulos, pp. 405-24. Oxford: Oxford University Press.

Stalnaker, R. 2002. Common ground. Linguistics and Philosophy 25: 701-21.

Starr, W. forthcoming. A preference semantics for imperatives. Semantics and Pragmatics.

Stebbing, S. 1939. Thinking to Some Purpose. New York: Penguin

Steele, C. M. 1988. The psychology of self-affirmation: sustaining the integrity of the self. Advances in Experimental Social Psychology 21: 261-302.

Veltman, F. 1996. Defaults in update semantics. Journal of Philosophical Logic 25(3): 221-61

Weber, M. 1967. On Law in Economy and Society. New York: Clarion. 